\title{
TORSIONAL DEFORMATION AND FATIGUE BEHAVIOUR OF 6061 ALUMINIUM ALLOY
}

\author{
M. MARINI AND A. B. ISMAIL \\ School of Materials and Mineral Resources Engineering, \\ University Sanis Malaysia, 14300 Nibong Tebal, Penang, Malaysia. \\ marini.marno@gmail.com
}

\begin{abstract}
Torsional deformation and fatigue behaviour of both solid and thin-walled tubular specimens made from as-received and heat treated 6061 aluminium alloy were studied. 6061 aluminium alloy have been widely used as a candidate material in automobile, aerospace, aircraft and structural application because of their superior mechanical properties such as high strength to weight ratio, good ductility and others. The differences in cyclic deformation and fatigue behaviours between round and solid specimens where a stress gradient exist, and thin-walled tubular specimens where a uniform stress state is commonly assumed, are also discussed. Von Mises and Tresca criteria has been used to predict the monotonic and cyclic deformation curve and compared to the torsional data obtained from the experiment. Both Tresca and Von Mises fit the experimental curve but Tresca estimation shows a curve that fits the experimental curve better than the Von Mises Fatigue life of the specimens were recorded and presented in the S-N curve and shows that heat treated T6 alloy exhibit higher fatigue life and fatigue strength compared to the as-received alloy. Through fractographic analysis, failure criteria of fracture surfaces were observed and discussed.
\end{abstract}

ABSTRAK: Ubah bentuk kilasan dan kelakuan lesuk edua-dua specimen berbentuk rod dan tiub berdinding nipis yang diperbuat daripada aloi aluminium 6061 seperti yang diterima dan dirawat haba adalah dikaji. Aloi aluminium 6061 digunakan secara meluas sebagai bahan di dalam aplikasi bidang aeroangkasa, automobil, pesawat udara, danstruktural kerana mempunyai sifat-sifat mekanikal yang hebat seperti berkekuatan tinggi bagi nisbah berat, kemuluran yang tinggi dan lain-lain.Perbezaan ubah bentuk kitaran dan kelakuan lesu di antara spesimen berbentuk rod dimana wujudnya kecerunan tegasan dengan spesimen tiub berdinding nipis di mana diandaikan keadaan tegasan adalah seragam juga dibincangkan. Kriteria Von Mises dan Tresca digunakan untuk meramalkan ubah bentuk lengkung monotonik dan kitaran yang kemudian dibandingkan dengan data kilasan yang diperolehi dari eksperimen. Kedua-duaTresca dan Von Mises menunjukkan lengkung yang menepati lengkung eksperimen tetapi anggaranTresca memberikan lengkung yang lebih menepati lengkung eksperimen jika dibandingkan dengan Von Mises. Hayat lesu spesimen yang kemudian direkodkan dan ditunjukkan dalam bentuk lengkung S-N menunjukkan bahawa aloi T6 yang dirawa tmempamerkan hayat lesu dan kekuatan lesu yang lebih tinggi berbanding aloi seperti yang diterima.Melalui analisis fraktografi, kriteria kegagalan permukaan patah diperhatikan dan dibincangkan.

KEYWORDS: fatigue; 6061 aluminium alloy; torsional deformation; fractography 


\section{INTRODUCTION}

6061 aluminium alloy finds various usages as structural application and welded assemblies including truck components, aircraft, automotive parts, marine applications and others. This alloy shows great promise for more applications [1]. 6061 aluminium alloy is a heat treatable, wrought $\mathrm{Al}-\mathrm{Mg}-\mathrm{Si}$ alloy. It is well known for its superior mechanical properties such as good ductility, high strength to weight ratio and others. It also has capability to resist cracks because of one of its properties which is high toughness. It can be considered as a potential candidate material for automobile and aerospace sectors where high crack arrest capabilities and high strength with reduced weight will contribute to crash worthy design of automobiles and aircrafts structure [2].

Fatigue is the principal cause of premature failure of engineering components where it can be subjected to cyclic stresses during service condition which may locally exceed the yield strength of particular material. This situation led to the demand for increasing vehicle safety that becomes a matter of concern [3, 4]. Failure of bus drive shaft and power transmission shaft are some examples of torsional fatigue failures [5, 6].

The objectives of this paper are to study the cyclic deformation behaviour of 6061 aluminium alloy and the response of cyclic torsion to the morphology of fracture. The different in fatigue life for the heat treated and different specimen geometry also have

\section{EXPERIMENTAL PROCEDURE}

\subsection{Material and Specimens}

The material used in this investigation was a 6061 as-received aluminium alloy and with T6 heat treatment. The specimens were machined into round solid specimen and tubular specimen shown in Fig. 1. The specimen were heat treated into precipitation hardening (T6). For solid specimens, solution heat treatment was performed at $530{ }^{\circ} \mathrm{C}$ for 55 minutes followed by water quenching while for tubular specimen, solution heat treatment was performed at $530^{\circ} \mathrm{C}$ for 35 minutes. Aging treatment was carried at $175{ }^{\circ} \mathrm{C}$ for 8 hours. The chemical composition and the mechanical properties are shown in Table 1 and 2 , respectively. 

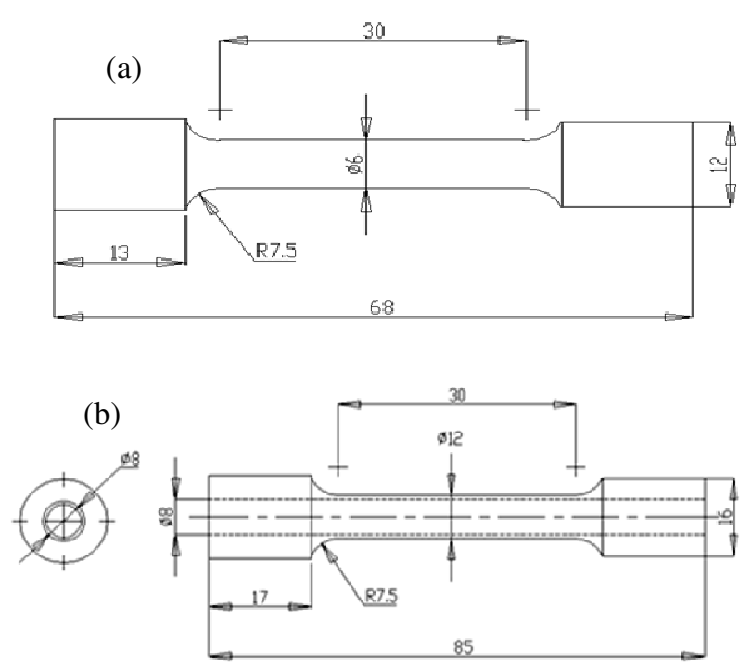

Fig. 1: Geometry and dimension of the specimens used in the torsional fatigue.

(a) Solid specimen. (b) Thin-walled tubular specimen.

Table 1: Chemical composition of the 6061 as-received and 6061-T6 aluminium alloy.

\begin{tabular}{|c|c|c|c|c|c|}
\hline $\begin{array}{c}\text { 6061 Al } \\
\text { Alloy }\end{array}$ & Mg & Si & Fe & Cu & Mn \\
\hline as-received & 0.66 & 0.58 & 0.18 & 0.20 & 0.0075 \\
\hline T6 & 0.72 & 0.67 & 0.31 & 0.36 & 0.0630 \\
\hline
\end{tabular}

Table 2: Monotonic torsional mechanical properties of the 6061 as-received and 6061-T6 aluminium alloy.

\begin{tabular}{|c|c|c|}
\hline 6061 Al Alloy & As-received & T6 \\
\hline Ultimate strength, $\tau_{\mathrm{u}}(\mathrm{MPa})$ & 160.27 & 211.77 \\
\hline Yield strength, $\tau_{\mathrm{y}}(\mathrm{MPa})$ & 146.30 & 192.95 \\
\hline Modulus, $\mathrm{G}(\mathrm{GPa})$ & 15.87 & 18.59 \\
\hline Strength Coefficient, $\mathrm{K}_{0}(\mathrm{MPa})$ & 202.64 & 258.05 \\
\hline Strength hardening exponent, $\mathrm{n}_{0}$ & 0.063 & 0.048 \\
\hline
\end{tabular}

\subsection{Experiments and Results}


Marini and Ismai

A Test Resource instruments (TR1) with servo-hydraulic axial-torsion load frame was applied for the fatigue experiments using the solid and tubular specimens. The machine is capable of exerting a $50 \mathrm{kN}$ axial force and a $1000 \mathrm{Nm}$ torque on test specimens.

The testing system is equipped under environment of MTL7 basic software with 2350 controller, computer control, and data acquisition. The operating frequency for fatigue tests is $1 \mathrm{Hertz}$ and tests took from 2 hours to 4 days. All tests were performed in load control, and conformed to ASTM E2207. All tests were controlled using the computer and conducted in the ambient air. Torque and shear strain value were recorded during the first ten cycles of the fatigue test in order to determine the initial cyclic hardening or softening of the specimens. Failure of the specimens has been determined when the sample breaks and separate into two pieces and this situation most likely to occur on the solid specimen. For specimens that do not separate into two pieces, the specimens was considered to have failed when there is either $5 \%$ or $10 \%$ force drop from the previously recorded torsional peak loads.

Monotonic torsion test were conducted in order to obtain the monotonic properties of the material. Cycles to failure were recorded when the specimen failed. The fractured surface of every specimen has been observed under the scanning electron microscopy.

\section{RESULTS AND DISCUSSION}

\subsection{Monotonic and Cylic Deformations}

From measured torsional loading and specimen dimensions, shear stress $(\tau)$ for solid and tubular specimen was calculated. $0.02 \%$ offset method were used on the monotonic shear stress strain curve in order to determine the shear yield strength, $\left(\tau_{\mathrm{y}}\right)$. Shear modulus (G) was determined by calculating the slope of the elastic region from the monotonic shear stress-strain curve obtained. The relation between true shear stress $(\tau)-$ shear strain $(\gamma)$ that has been plotted was described by Ramberg - Osgood equation:

$$
\gamma=\gamma_{e}+\gamma_{p}=\frac{\tau}{G}+\left(\frac{\tau}{K_{o}}\right)^{\frac{1}{n_{o}}}
$$

From equation (1), shear strength coefficient or material constant, $\mathrm{K}_{\mathrm{o}}$ and strain hardening exponent, $\mathrm{n}_{\mathrm{o}}$ describe the monotonic shear stress-plastic strain relationship. Value of $\mathrm{K}_{\mathrm{o}}$ and $\mathrm{n}_{\mathrm{o}}$ can be determine from the intercept and slope of the best line fit to the data plotted on a log-log scale of true shear stress- plastic strain curve. Common yield criteria which are Von Mises and Tresca criterion has been used to predict the shear stressstrain behavior of the material and compared to the torsional data obtained from the experiment. The prediction was made by using the Ramberg-Osgood equation, based on Von Mises and Tresca criterion respectively:

$$
\begin{aligned}
& \mathrm{K}_{\mathrm{o}}=\mathrm{K}\left(\frac{1}{3}\right)^{(\mathrm{n}+1) / 2} \text { and } \mathrm{n}_{\mathrm{o}}=\mathrm{n} \\
& \mathrm{K}_{\mathrm{o}}=\mathrm{K}\left(\frac{\mathrm{K}}{2}\right)\left(\frac{2}{3}\right)^{\mathrm{n}} \text { and } \mathrm{n}_{\mathrm{o}}=\mathrm{n}
\end{aligned}
$$


Figure 2 shows the comparison between experimental monotonic torsion curve with Von Mises and Tresca criterion. From this figure, it can be seen that both Tresca and Von Mises fit the experimental curve but Tresca estimation shows a curve that fits the experimental curve better than the Von Mises. The Tresca criterion assumes that the yielding and plastic deformation will occur when the shear stress on the plane of maximum shear reaches a critical value where the mechanism of plastic deformation occur due to the slip of crystal planes [7,8].

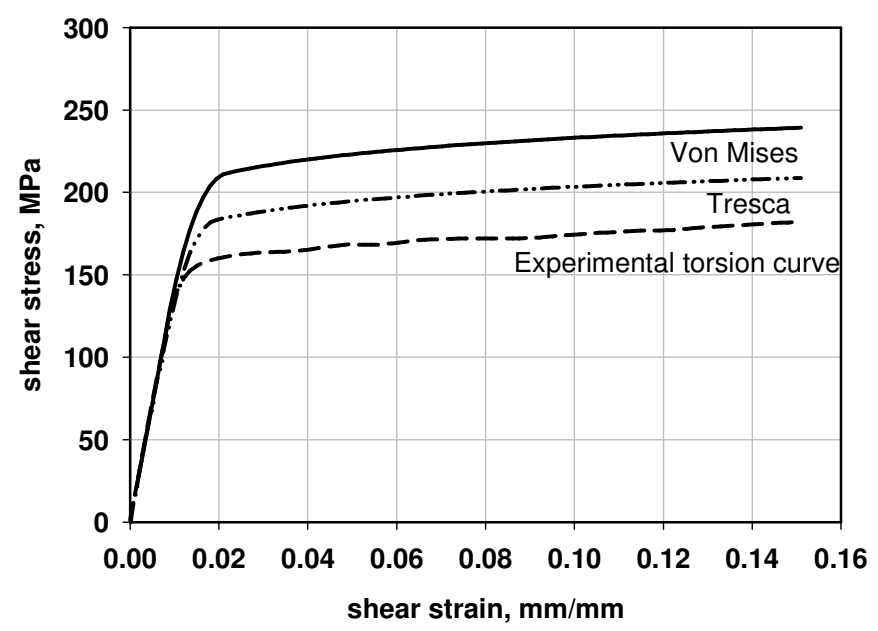

Fig. 2: Comparison between experimental monotonic torsion curve with Von Mises and Tresca criterion for 6061 aluminium alloy.

From the torsion fatigue test data, the behaviour of cyclic torsional deformation was obtained. Using the Ramberg-Osgood type equation, the cyclic shear stress-strain behaviour can also be characterized [7]. One of the most important fatigue characteristics for the major part of the fatigue life is the plastic stress-strain response of the material which have been characterizes from the basic stress-strain curve. By plotting the stable torsional stress amplitude against the torsional plastic strain on a logarithmic scale, the strain hardening exponent and strength coefficient have been determined. Figure 3 and 4 show the cyclic stress-strain curves for both alloys and Table 3 indicate the parameters obtained. From the figures, we can see that both alloy were cyclically hardened, this is due to the low dislocation densities in this alloy. But in hard materials such as steels, it will become cyclically soften. 


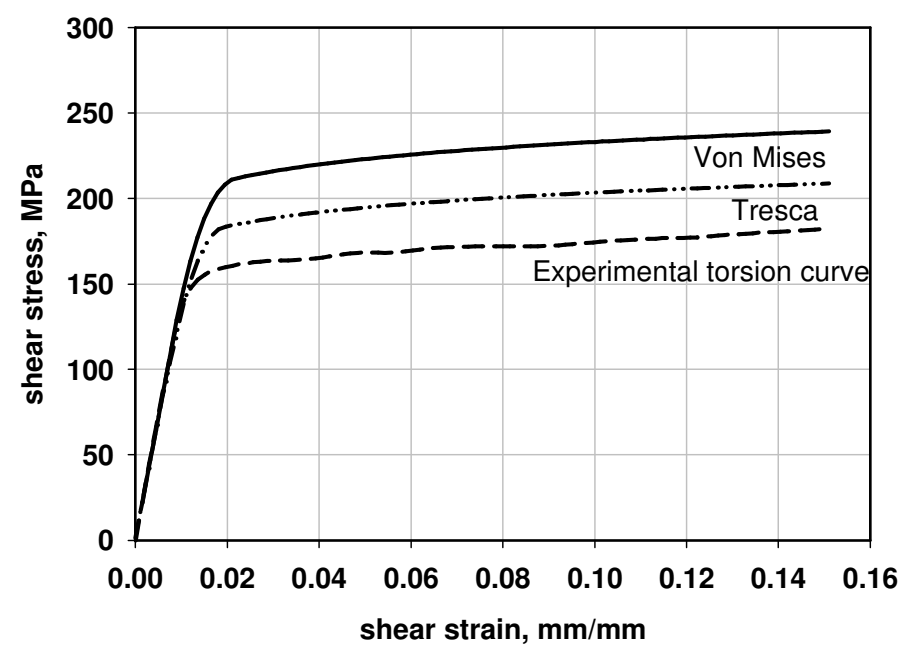

Fig. 3: Comparison between monotonic and cyclic stress-strain curve for as-received 6061 aluminium alloy

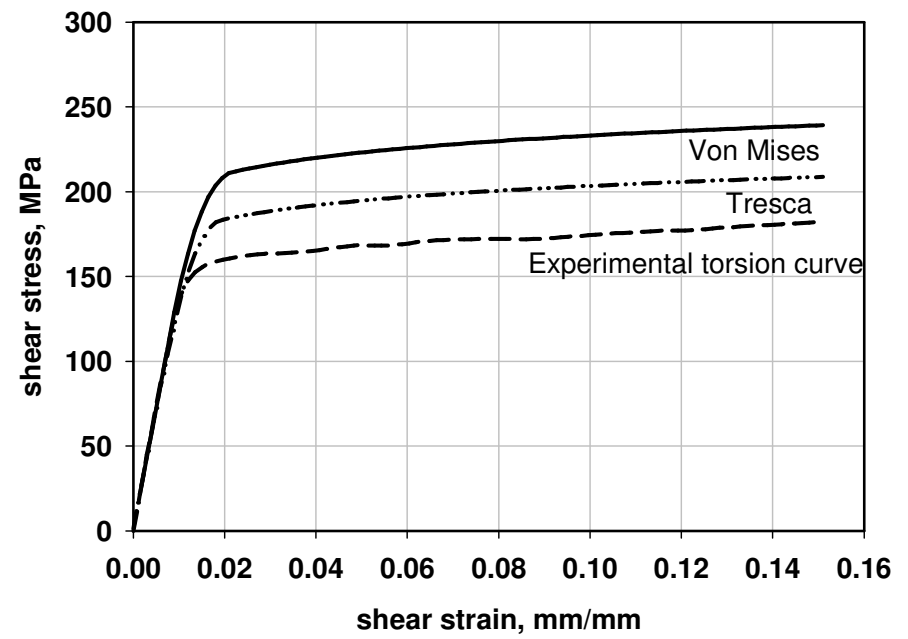

Fig. 4: Comparison between monotonic and cyclic stress-strain curve heat treated 6061-T6 aluminium alloy.

Table 3: Cyclic stress-plastic strain parameters for as-received 6061 aluminium alloy.

\begin{tabular}{|c|c|c|}
\hline 6061 Al Alloy & As-received & T6 \\
\hline Cyclic Hardening Coefficient, K` (MPa) & 257.532 & 301.505 \\
\hline Cyclic Hardening Coefficient, n` & 0.055 & 0.034 \\
\hline
\end{tabular}

\subsection{Torsional and Fatigue Behaviour on Solid and Tubular Specimen}


Marini and Ismai

Under torsional cyclic loading, the life for solid specimens were longer compared to the tubular specimen because of the crack which retarded crack growth due to the subsurface growth toward the center of the specimen and slowly growing inward as shown in Fig. 5. So, there is more material through which crack can grow inward and this makes a solid specimen last longer and also due to the stress gradient effect which lower the stress toward the center of the specimen cross section and led to a longer fatigue life [7]. From Fig. 6, we can also found that for the specimens that were heat treated into T6 condition gives longer fatigue life compared to the as-received specimens. This is due to the solution heat treatment process that greatly affects the fatigue properties of this alloy which might be related to an increasing the hardness and strength of this alloy [9].

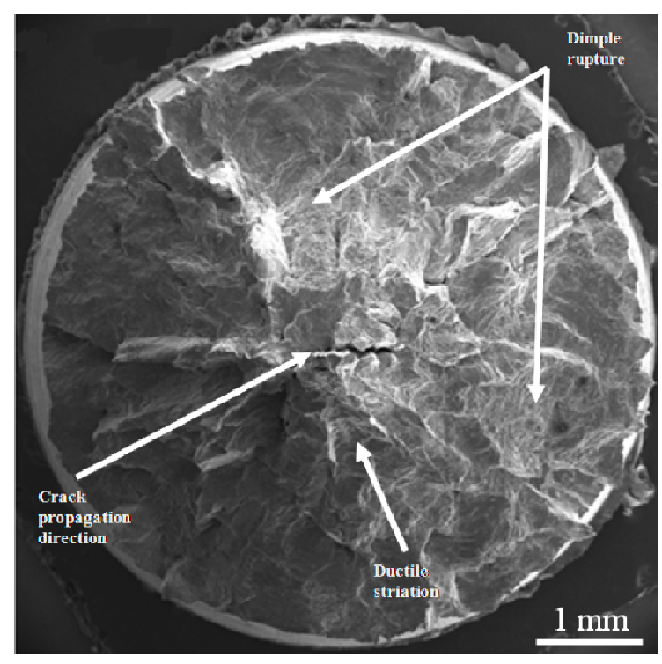

Fig. 5: Fractograph showing overall appearance of fracture surface.

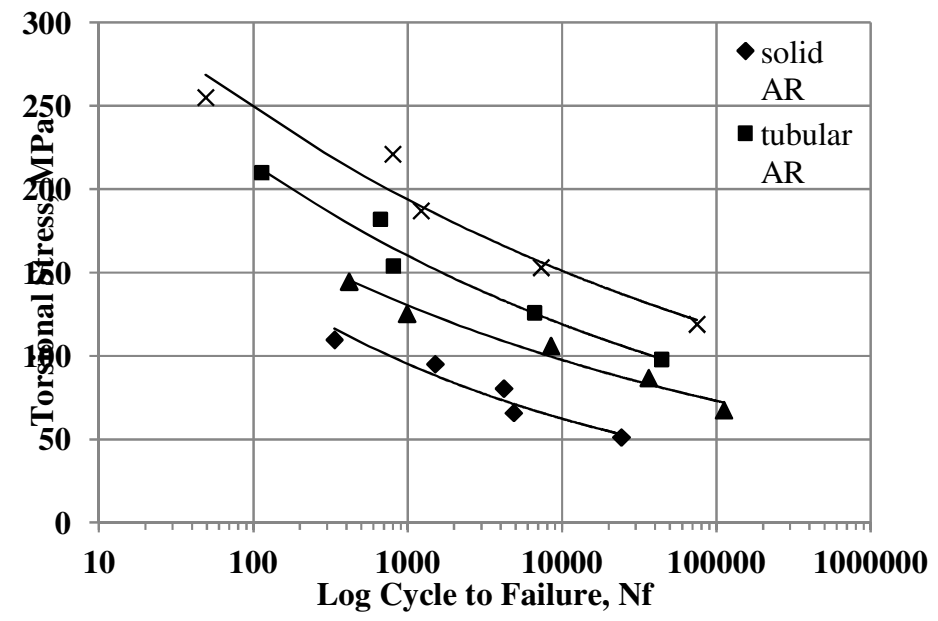

Fig. 6: S-N curve fatigue life for both solid and tubular as-received and heat treated 6061 aluminium alloy. 
Marini and Ismai

\subsection{Analysis of Fatigue Fracture Surfaces}

Figures 5 and Fig.7-10 show torsional fatigue fracture surface features from this investigation. Figure 5 shows the overall appearance of fracture surfaces which shows peak and valley fracture surface that pointing towards the middle of the specimen. The crack initiation stage of fatigue was called stage I. Crack initiates from the surface of the specimen where the shear stresses values gives the highest level but there is no indication of initiation sites observed. When the crack initiated, the local stress increased, different states of stress were formed around the fatigue crack initiation and the crack begin to propagate when the local shear stress exceeded the shear strength of the material [10].

Figure also shows that cracks propagate toward the center of the specimen. This fracture surface also called "starry" pattern fracture surface [11]. Crack propagation which is stage II occur when the crack has progressed a small distance from the surface of the specimen. Smooth specimens that were subjected to torsional fatigue loading will proceed to Mode II after crack initiation stage. This means that crack initiation occurred on the planes where the largest shear stress amplitude exist. When the shear crack reached a threshold value, which was a function of the material and number of cycles to failure, crack branching would occur, and the crack would propagate in the same direction [10, 12]. Figure 7 shows shear dimples fracture surface resulting from torsional fatigue loading. This fracture surface describes ductile fracture that formed through a process which called void coalescence. Slip is the cause of plastic deformation of material that occurred between the voids. Since this slip extends to the free surface of the void, then slip traces form shown in Fig. 8. Voids are initiated by fracture of the particles. It were formed at second-phase particle which is $\mathrm{Mg}_{2} \mathrm{Si}$ due to the separation of material internally will combine to develop the fracture surface After that, the connecting material will continue to deform by slip, allowing the voids to expand and connect along the fracture path. Some particles lies in the dimples of the mating fracture surface shown in Fig. 9 while some of them fell out during separation of the fracture surface, so that in the fractograph some dimples are empty $[2,13,14]$.

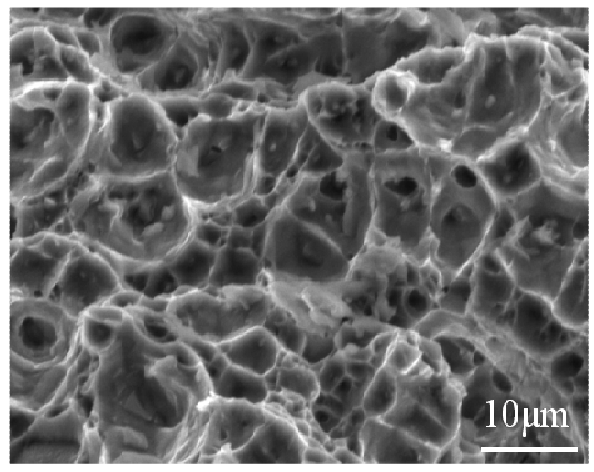

Fig. 7: Fractograph showing shear dimples fracture surface resulting from torsional loading. 


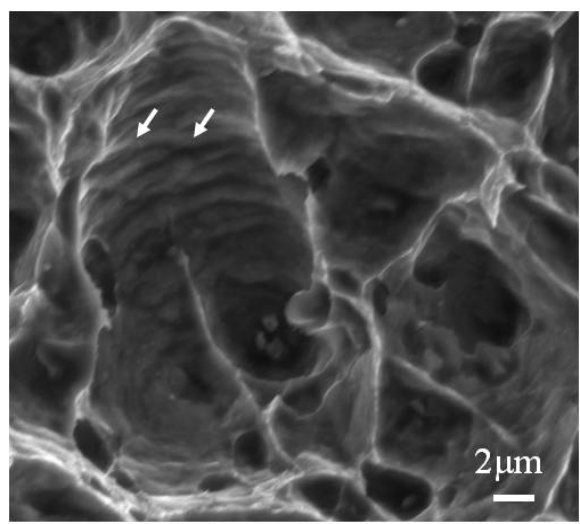

Fig. 8: Fractograph showing slip traces (arrows) on the side of the dimples.

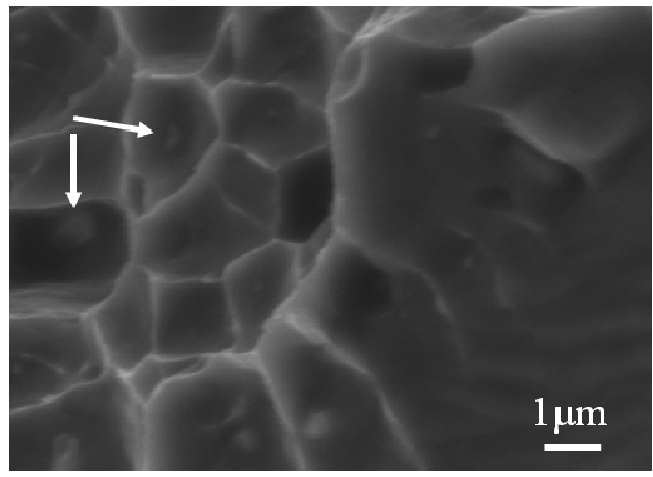

Fig. 9: Fractograph showing dimples with particle lying inside.

Figure 10 shows that the fracture surface contained ductile striation. Striations formed during crack propagation stage. Large second-phase particles and inclusions in 6061 aluminium alloy can change the local crack growth rate resulting in fatigue striation spacing. When a fatigue crack approaches such particles, it is briefly retarded if the particle permits intact or is accelerated if the particle cleaves $[2,10]$.

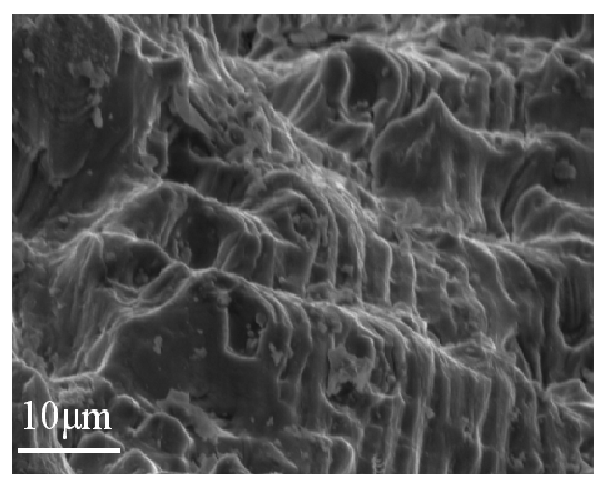

Fig. 10: Fractograph showing typical ductile striation in fatigue fractures. 
Marini and Ismai

Stage III which is the final overload fracture was the final stage in fatigue crack propagation stage. In this specimen, since the cracks propagate towards the center of the specimen, the final rupture appeared to be at the center of the specimen shows central fibrous fracture. From the analysis, it also indicates that the material was adequate for the low applied stresses because of the final fracture of the surface area become smaller compared to the initial total area [9].

\section{CONCLUSION REMARKS}

From the results and analysis that have been presented in the paper, the following concluding remarks can be drawn.

a. Tresca estimation provided the best predictions when predicting torsional monotonic and cyclic behaviour. It shows a curve that fits the experimental curve better than the Von Mises criterion.

b. From the comparison of both monotonic and cyclic shear stress-strain curve, both alloys tend to harden when cyclic torsional loading were applied to them.

c. Solid specimens give longer fatigue life compared to tubular specimens due to stress gradient effect. Heat-treated specimens also give longer fatigue life compared to the as-received specimens due to the solution heat treatment process that improves the fatigue properties.

d. It was observed that crack initiate at the surface of the specimens and then propagate towards the center of the cross sectional area of the specimens. It also observed that, the final fracture surface area have been decreased compared to the total area. This shows that the material were suitable for the applied stress.

\section{ACKNOWLEDGEMENT}

The authors express their thanks to the Universiti Sains Malaysia and USM Fellowship for supporting this work.

\section{REFERENCES}

[1] J. R. D. A. Joseph R. Davis, Aluminum and aluminum alloys: ASM International, 1993.

[2] B. F. Jogi, P. K. Brahmankar, V. S. Nanda, and R. C. Prasad, "Some studies on fatigue crack growth rate of aluminum alloy 6061," Journal of Materials Processing Technology, vol. 201, pp. 380-384, 2008.

[3] U. Sánchez-Santana, C. Rubio-González, G. Mesmacque, A. Amrouche, and X. Decoopman, "Effect of fatigue damage induced by cyclic plasticity on the dynamic tensile behavior of materials," International Journal of Fatigue, vol. 30, pp. 1708-1719, 2008/11// 2008.

[4] U. Sánchez-Santana, C. Rubio-González, G. Mesmacque, and A. Amrouche, "Effect of fatigue damage on the dynamic tensile behavior of 6061-T6 aluminum alloy and AISI 4140T steel," International Journal of Fatigue, vol. 31, pp. 1928-1937, 2009/12// 2009.

[5] D. Duffner, "Torsion fatigue failure of bus drive shafts," Journal of Failure Analysis and Prevention, vol. 6, pp. 75-82, 2006. 
IIUM Engineering Journal, Vol. 12, No. 6, 2011: Special Issue in Science and Ethics

Marini and Ismai

[6] S. K. Bhaumik, R. Rangaraju, M. A. Parameswara, M. A. Venkataswamy, T. A. Bhaskaran, and R. V. Krishnan, "Fatigue failure of a hollow power transmission shaft," Engineering Failure Analysis, vol. 9, pp. 457-467, 2002.

[7] D. McClaflin and A. Fatemi, "Torsional deformation and fatigue of hardened steel including mean stress and stress gradient effects," International Journal of Fatigue, vol. 26, pp. 773784, 2004.

[8] G. B. M. Darrell F.Socie, Multiaxial Fatigue. Warrendale, Pa: Society of Automotive Engineers, Inc., 2000.

[9] R. Sadeler, Y. Totik, M. GavgalI, and I. Kaymaz, "Improvements of fatigue behaviour in $2014 \mathrm{Al}$ alloy by solution heat treating and age-hardening," Materials \& Design, vol. 25, pp. 439-445, 2004.

[10] H. X. E. Bayraktar, F. Ayari, C. Bathias, "Torsional fatigue behaviour and damage mechanisms in the very high cycle regime," Archives of Materials Science and Engineering, vol. 43, pp. 77-86, 2010.

[11] D. J. Wulpi, Understanding How Components Fail, 2nd Edition ed.: ASM International, 1999.

[12] C. Makabe and D. F. Socie, "Crack growth mechanism in precracked torsional fatigue specimens," Fatigue \& Fracture of Engineering Materials \& Structures, vol. 24, pp. 607-615, 2001.

[13] A. C. Charlie R.Brooks, Metallurgical Failure Analysis: McGraw-Hill, Inc., 1993.

[14] J. G. Cowie and F. R. Tuler, "Comparison of shear and tensile fracture in high strength aluminum alloys," International Journal of Fracture, vol. 47, pp. 229-239, 1991.

\section{NOMENCLATURE}

$\begin{array}{ll}G & \text { Shear modulus } \\ K_{o} & \text { Material constant } \\ n_{o} & \text { Strain hardening coefficient }\end{array}$

$\mathrm{GPa}$

GREEK LETTERS

$\tau$

$\gamma$

$\gamma_{e}$

$\gamma_{p}$
Shear stress

Shear strain

Elastic shear strain

Plastic shear strain
$\mathrm{MPa}$
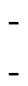
IIUM Engineering Journal, Vol. 12, No. 6, 2012: Special Issue in Science and Ethics

Marini and Ismail 